\title{
Morphology and Anatomy of the Vegetative Organs and Scapes from Aphorocaulon (Paepalanthus, Eriocaulaceae)
}

\author{
Vera Lúcia Scatena* and Michele Marcelino Rosa \\ Depto. de Botânica, IB - UNESP, C.P. 199, 13506-900, Rio Claro, São Paulo. Brasil. Bolsistas CNPq
}

\begin{abstract}
The roots, stems, scapes and leaves anatomy of species of Paepalanthus subsect. Aphorocaulon were studied. The plants showed short stems with rosulate leaves and possessed an aerial axis branching, the paraclades. These species had roots with uniseriate epidermis and cortex with isodiametric cells. Short stems and paraclades presented a thickening resulting from the activity of the pericycle named prymary thickening meristem (PTM). They presented a similar anatomical feature. The scapes presented discontinuous endodermis, sinuous pericycle, and the cortex had proeminent ribs (5-6) and the leaves showed epidermis with elongated cells in the longitudinal orientation, cell walls slightly thickened, stomata present only on the abaxial surface, with special leaf substomatal chambers, collateral vascular bundles with a double sheath. Those anatomical characteristics are common to Aphorocaulon species and are those typical of plants that grow in the rupestrian field habitats.
\end{abstract}

Key words: Morphology, anatomy, Paepalanthus, Aphorocaulon

\section{INTRODUCTION}

The Eriocaulaceae is a pantropical family comprising 10 genera and about 1200 species (Giulietti \& Hensold, 1990), of which more than 90\% belong to the genera Eriocaulon L., Paepalanthus Kunth., and Syngonanthus Ruhland. They form frequent components of the vegetation in montane shallow pools or swamps, especially on sandy ground. The greatest concentration of species is in South America, especially in the rock savannas ("campos rupestres") of Minas Gerais and Bahia (Brazil) and on the table mountains ("Tepuis") of South Venezuela (Giulietti et al., 1995).

Paepalanthus species grows in several habitats. Such variability of habitats associated to the great morphological diversity of habits (it includes from plants of some millimeters up to $2 \mathrm{~m}$ of height), of inflorescence, of flowers, and of fruits and seeds. That turns the genus into highly polymorphic, having been besides recognized recently as paraphyletic by Giulietti et al. (1995).

Some species of Paepalanthus as $P$. bromelioides, P. microphyllus, $P$. paulinus, $P$. robustus, $P$. scleranthus and $P$. speciosus were

\footnotetext{
" Author for correspondence
} 
studied by Castro (1986) and Castro \& Menezes (1995) who described the anatomy of the vegetative organs, specially of the leaves. Hensold (1988) studied species of the subg. Xeractis and used the leaves and scapes anatomical features in the taxonomy. Scatena \& Moraes (1996) studied the anatomy of roots, leaves and scapes of $P$. vellozioides, $P$. latipes, $P$. pauciflorus, $P$. macropodus and $P$. planifolius relating the anatomical features to the taxonomy position in the group.

The anatomical vegetative organs and scapes of Eriocaulaceae have been used for taxonomical purposes in different hierarchical levels. This paper proposes the morphological and anatomical characterization of the species of subg. Paepalocephalus subsect. Aphorocaulon to support a future phylogenetic analysis of genus. The possible adaptative significance of the variation found in the different organs is indicated as well.

\section{MATERIAL AND METHODS}

The material examined was collected from natural habitats in the campos rupestres of central Brazil. Specimen of each species have been deposited in the Herbarium of the Botanical Department of the São Paulo University (SPF) CFCR = Collections of the Flora of the Campos Rupestres.

Paepalanthus subg. Paepalocephalus sect. Eriocaulopsis subsect. Aphorocaulon: $P$. applanatus Ruhland (Silva et al. CFCR 8018); $P$. geniculatus (Bong.) Kunth. (Hensold CFCR 4219); P. gibbosus Silveira (Giulietti CFCR 57); P. incanus (Bong.) Koern. (Zappi et al. CFCR 10527); P. macrocephalus (Bong.) Koern. (Silva et al. CFCR 11126); P. aff. phaeocephalus Ruhland (Giulietti 1073).

For anatomical studies using the light microscope, sections were cut by hand in the median portion of adult roots, stems, scapes, and leaves, boiled in water to expand the tissues, and later transferred to $70 \%$ alcohol. For the stems, the sections were made in the median portion of the short stems and paraclades. At least four individuals of each species were used. The sections were stained with fuchsin and astra blue (Roeser, 1962) and mounted in glycerine jelly.

\section{RESULTS}

$P$. macrocephalus, $P$. aff. phaeocephalus and $P$. gibbosus (Fig. 2) presented thick stems. Other species such as $P$. applanatus, $P$. geniculatus, and $P$. incanus (Fig. 1) showed less thicker stems. All species possessed adventitious roots growing from the basal portions stems. The plants presented short stems with rosulate leaves where branched aerial axis denominated paraclades (system of inflorescences) growth. According to the species, paraclades presented different lenghts, supporting the sapes that were nvolved by the spathe (Figs. 1-2).

The roots were thin, delicate (Figs. 1-2) and brownish. Figures 3-6 show the roots cross sections. $P$. macrocephalus was similar to $P$. applanatus, and $P$. aff. phaeocephalus was similar to $P$. geniculatus. All species presented uniseriate epidermis (E) with thin wall cells (Figs. 3-6). 

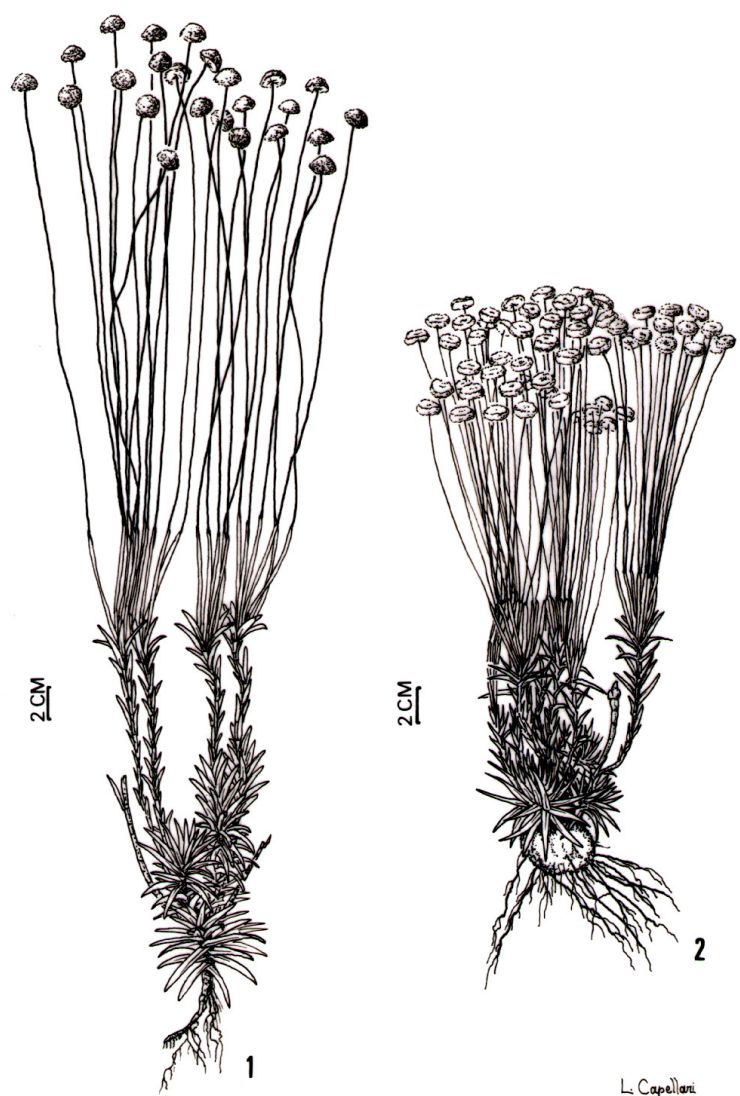

The cortex (C) presented isodiametric parenchymatous cells with thin cell walls. It had a uniseriate layer in $P$. gibbosus and $P$. incanus (Figs. 5-6) or biseriate layers in the other species (Figs. 3-4). The endodermis (EN) showed a biseriate layer with thick cell walls in $P$. macropodus and P. applanatus (Fig. 3) or a uniseriate layer in the other species (Figs. 46). The pericycle $(\mathrm{P})$ had a uniseriate layer and with thin cell walls in $P$. gibbosus and $P$. incanus (Figs. 5-6) or thickened cell walls in the other species (Figs. 3-4). The vascular cylinder showed one central metaxylem element in $P$. gibbosus and $P$. incanus (Figs. 5-6), or various metaxylem elements in the other species (Figs. 3-4).

The stems cross sections diagrams of the studied species are shown in Figures 7-12. The median 

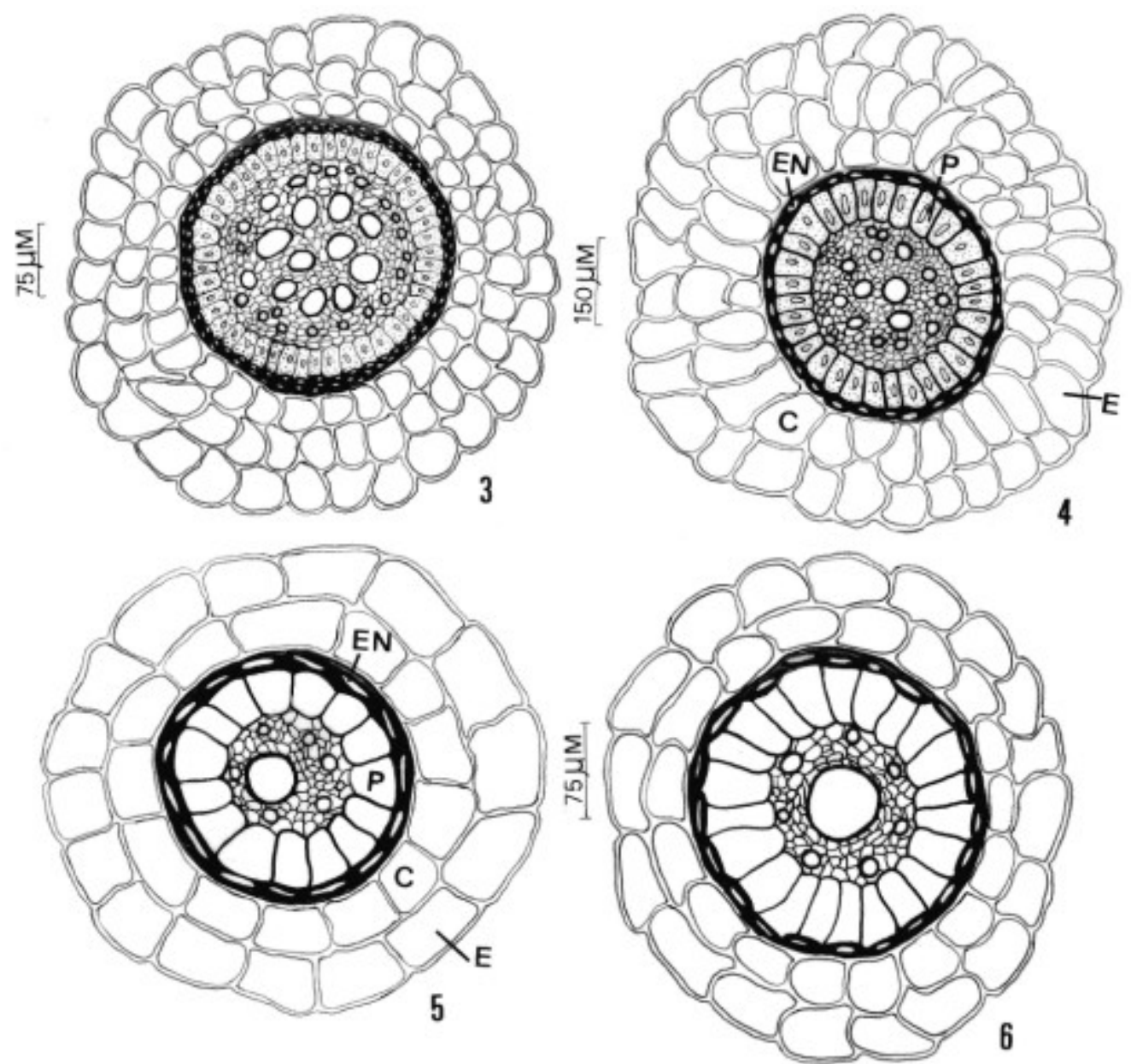

Figures 3-6 - Roots cross sections of P. applanatus (Fig. 3), P. geniculatus (Fig. 4), P. gibbosus (Fig. 5) and P. incanus (Fig. 6). $\mathrm{C}=$ Cortex; $\mathrm{E}=$ Epidermis; $\mathrm{EN}=$ Endodermis; $\mathrm{P}=$ Pericycle.

portions of short stems showed cortical adventitious roots (Ar) (Figs. 8,10). The pericycle and the vascular bundles were oriented to the branchings originating the paraclades. The short stems and the paraclades presented a thickening produced by the activity of the pericycle named prymary thickening meristem (PTM). Both of them had a similar anatomical feature. The median portions of paraclades (Figs. 7,9,11-12) showed anfivasal vascular bundles, and their distribution

was peripherical and cylindrical. In these portions the leaf traces (Lt) were observed (Fig. 12).

All the species studied possessed stem with uniseriate epidermal cells thin-walled. It was observed in P. geniculatus, $P$. gibbosus and $P$. incanus (Figs. 19-21). The cortex showed isodiametric parenchymatous cells with thin walls (Figs. 19-21). The endodermis (EN) was uniseriate and showed thin cell walls in P. incanus (Fig. 21) or slightly thick in the other species, as in $P$. geniculatus and $P$. gibbosus (Figs. 19-20). 

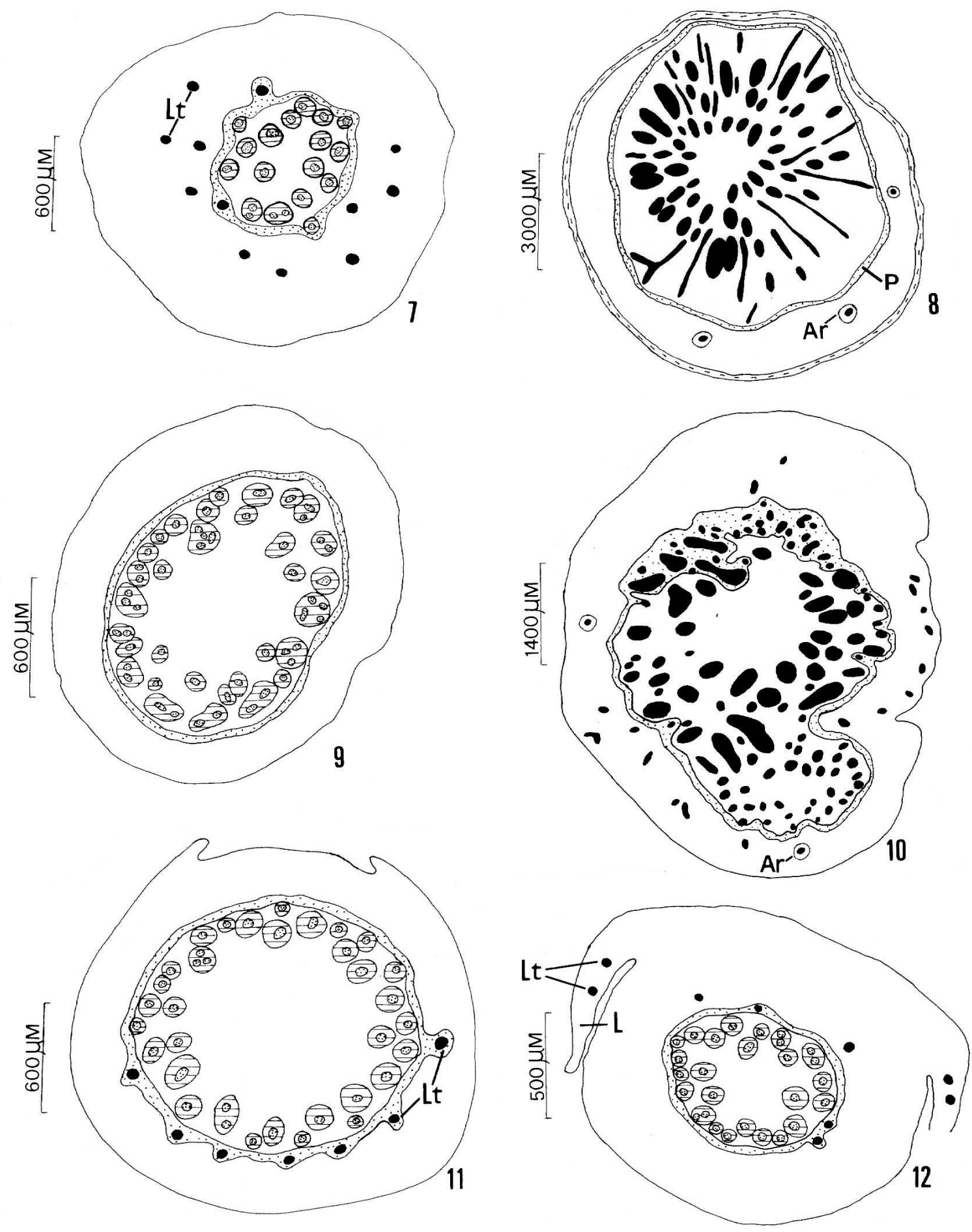

epidermis

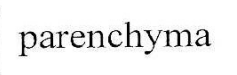

$\square$

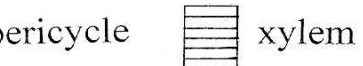
phloem $\therefore$ leaf trace adventitious root

Figures 7-12 - Cross sections diagrams of the stems of P. geniculatus (Fig. 7), P. gibbosus (Figs. 8-9), P. incanus (Figs. 10-11) and $P$. aff. phaeocephalus (Fig. 12). Ar $=$ Adventitious root; L = Leaf; Lt = Leaf trace; $\mathrm{P}=\mathrm{Pericycle}$. 
The pericycle $(\mathrm{P})$ had thickened cell walls and was biseriate in P. incanus (Fig. 21) or uniseriate in the other species, such as in $P$. geniculatus and P. gibbosus (Figs. 19-20). The vascular bundles (VB) in the cylinder were anfivasal and those cortical (CVB) ones were collateral (Fig. 19). The pith (PI) showed thin-walled parenchymatous cells in all species as observed in P. incanus (Fig. 21).

The cross sections diagrams of the scapes of the studied species can be seen in Figures 13-18. They were cylindrical with sclerenchymatous ribs. The number of ribs varied from 5 to 6 (Figs. 13-18). They showed discontinous endodermis and sinuous pericycle (Figs. 13-18).

All species studied presented scapes with uniseriate epidermis (E) with thickened cell walls as could be observed in $P$. gibbosus, $P$. macrocephalus and $P$. aff. phaeocephalus (Figs. 22-24). The stomata (S) were between the ribs, opposite the clorenchyma (Figs. 23-24). The cortex showed sclerenchymatous ribs alternated with clorenchyma (Figs. 22-24). The endodermis (EN) had thin wall cells and the pericycle (P) had slightly thickened cell walls (Figs. 22-24). All the vascular bundles were collateral and the pith (PI) had parenchymatous thin cell walls (Figs. 22-24).

The cross sections diagrams of the leaves of the studied species can be seen in figures 25-30. They possessed variated numbers of collateral vascular bundles, the larger ones alternating with the smaller ones. In $P$. applanatus (Fig. 25), $P$. geniculatus (Fig. 26) and P. gibbosus (Fig. 27) they were distributed near the adaxial epidermis, while in $P$. incanus (Fig. 28), P. macrocephalus (Fig. 29) and $P$. aff. phaeocephalus (Fig. 30) they were distributed in the middle of the mesophyll. The mesophyll was interrupted by the bundle-sheath extension (Figs. 25-30).

All species studied had the adaxial epidermis (E) with elongated cells. They were bigger than the abaxial ones and slightly thickened in all the species, as in $P$. macrocephalus (Fig. 31). Stomata (S) occurred only in the abaxial epidermis and presented special leaf substomatal chambers
(SC) (Figs. 31-33). They possessed short and long thickened cell walls. In cross section these cells constituted a chamber (Figs. 32- arrows). In longitudinal section these cells were between the stomata and presented a "U" shape (Fig. 34). In paradermal section these cells formed bridges under the stomata (Fig. 35 - arrows).

In all species the clorenchyma was constituted by palisade parenchyma in the adaxial face and spongy parenchyma in the abaxial face, as in $P$. macrocephalus (Fig. 31). The collateral vascular bundles had a double sheath: the external one (ES), of endodermal origin, with thin-walled parenchymatous cells and the internal one (IS), of pericyclic origin normally with one layer and thickened or sclerified cell walls (Fig. 25-31).

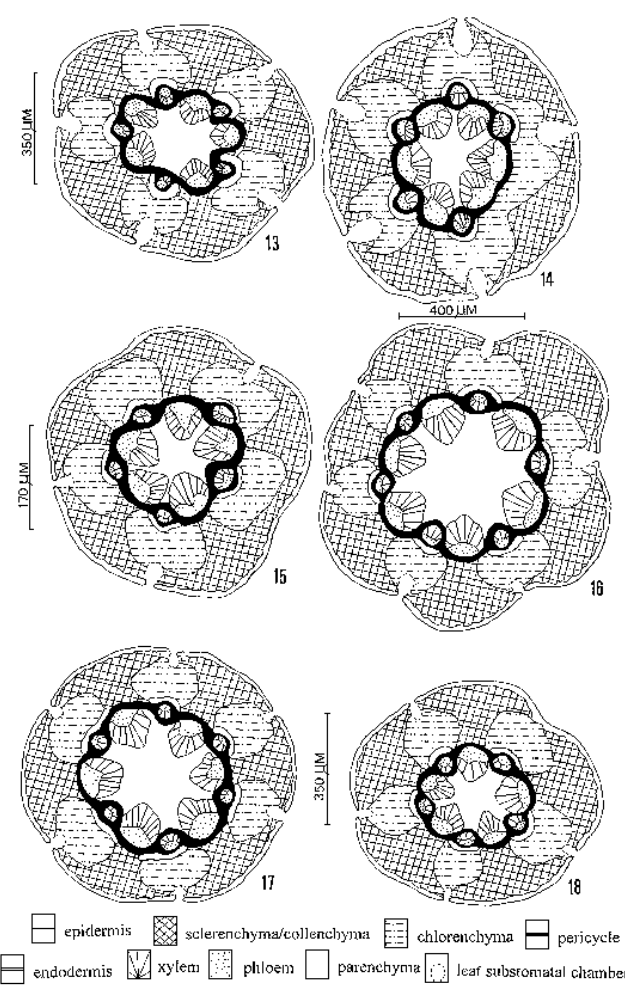

Figures 13-18 - Cross sections diagrams of the scapes of $P$. applanatus (Fig. 13), P. geniculatus (Fig. 14), $P$. gibbosus (Fig. 15), P. incanus (Fig. 16), $P$. macrocephalus (Fig. 17) and $P$. aff. phaeocephalus (Fig. 18) 


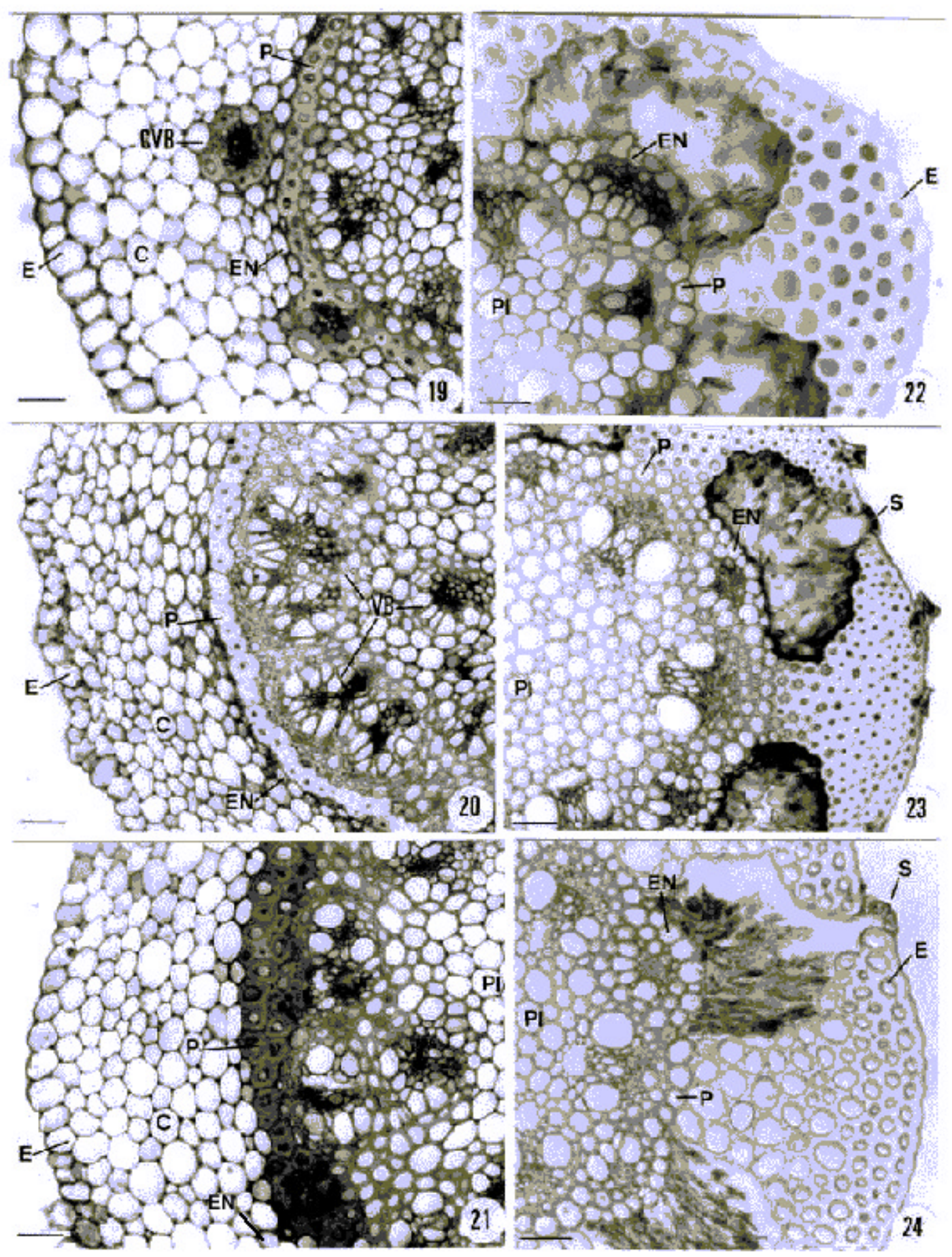

Figures 19-24 - Cross section photographs of stems and scapes of P. geniculatus (Fig. 19), P. gibbosus (Fig. 20), and $P$. incanus (Fig. 21). Scale $=60 \mu \mathrm{m}$. P. gibbosus (Fig. 22), P. macrocephalus (Fig. 23) and P. aff. phaeocephalus (Fig. 24). Fig. 22 scale $=30 \mu \mathrm{m}$. Fig. 23 scale $=60 \mu \mathrm{m}$. Fig. 24 scale $=50 \mu \mathrm{m} . \mathrm{C}=$ Cortex; CVB $=$ Collateral Vascular Bundles; $\mathrm{E}=$ Epidermis; EN = Endodermis; $\mathrm{P}=$ Pericycle PI = Pith; VB = Vascular Bundles; $\mathrm{S}=$ Stomata 


\section{DISCUSSION}

The species of genus Paepalanthus subsect. Aphorocaulon have short stems with rosulate leaves. The aerial branched axis denominated paraclades (system of inflorescences) growth from the short stems. That was defined by Sano (1999) for species of the genus Actinocephalus which showed similar morphology. The species studied in this work differed from the species of other groups of Paepalanthus as subg. Xeractis (Hensold 1988), subg. Platycaulon (Scatena \& Moraes 1996), and P. bromelioides (Castro 1986), which presented reduced stem with rosulate leaves without paraclades from where the scapes grew directly.

The morphological variation among the species of Paepalanthus was previously mentioned by Scatena et al. (1998), where the species grew either on stone or rock, or in recently decomposed stony soils, or in sandy soils that could be either humid or dry. Giulietti et al. (1995) described that; the habitat variability, associated to the great habit diversity in Paepalanthus turned the genus into highly polymorphic. All the species studied presented a similar habit and characterized the subsect. Aphorocaulon species. They were different from the other groups of Paepalanthus, confirming the polymorphism of the genus presented by Giulietti et al. (1995).

The roots of the Aphorocaulon species were thin and uniform. They did not store air in the cortex and were included in that uniform type described by Malmanche (1919) and Tomlinson (1969) for Eriocaulaceae in general. They were similar to those species of Paepalanthus as $P$. vellozioides, $P$. latipes and $P$. pauciflorus studied by Scatena $\&$ Moraes (1996) and P. hilairei studied by Scatena \& Barros (1996), where the roots were relatively thin with isodiametric cortical cells. The species studied in this work as well as those mentioned above, grew in areas where the soil did not flood at the rainy season.

Aphorocaulon species showed the median portion of the short stem, as well as the median portion of paraclades with the same anatomical features such as epidermis, cortex and vascular cylinder delimited by the pericycle. These characteristics were also observed in the stem of $P$. hilairei
(Actinocephalus bongardii, by Sano 1999) (Scatena \& Barros 1996).
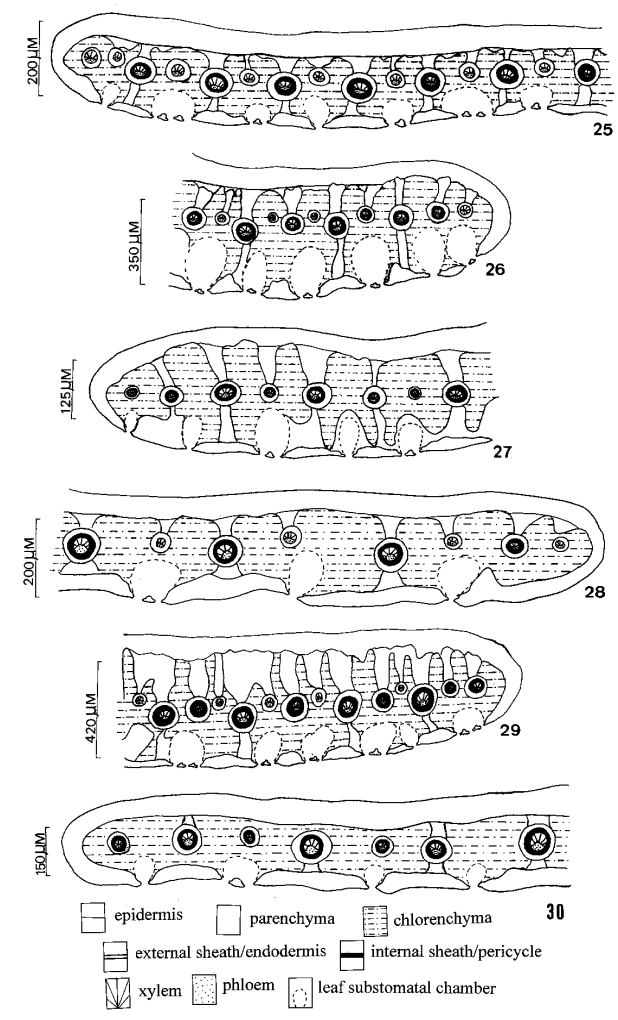

Figures 25-30 - Cross section diagrams of leaves of $P$. applanatus (Fig. 25), P. geniculatus (Fig. 6), $P$. gibbosus (Fig. 27), P. incanus (Fig. 28), $P$. macrocephalus (Fig. 29) and $P$. aff. phaeocephalus (Fig. 30)

In the studied species, the short stems and the paraclades presented thickening resulting from the activity of the pericycle named Primary Thickening Meristem (PTM). These regions showed anfivasal vascular bundles that were distributed in the peripheric region of the vascular cylinder close to the cells denominated by Tomlinson (1969) as sclerenchymatous cells, here called pericycle. The Primary Thickening Meristem was observed in some species of Syngonanthus (Eriocaulaceae) by Scatena \& Menezes (1996). PTM had the same configuration and the same position of the pericycle, where the adventitious roots, leaves, and scapes grew.

According to Tomlinson (1969), scape from Eriocaulaceae could present radial or bilateral symmetry. The Aphorocaulon species presented scapes with radial symmetry and salient ribs, while 
the species of Paepalanthus subg. Platycaulon sect. Divisi and Conferti presented scapes with bilateral symmetry and without salient ribs (Scatena et al. 1998). The number of ribs, according to Tomlinson (1969) could be used in the taxonomy of Eriocaulaceae. In the studied species, the scapes presented 5-6 ribs and that was important to characterize the species of the subsect. Aphorocaulon.

In all the species studied the leaves presented stomata in the abaxial face as in the other studied species of Eriocaulaceae. This was
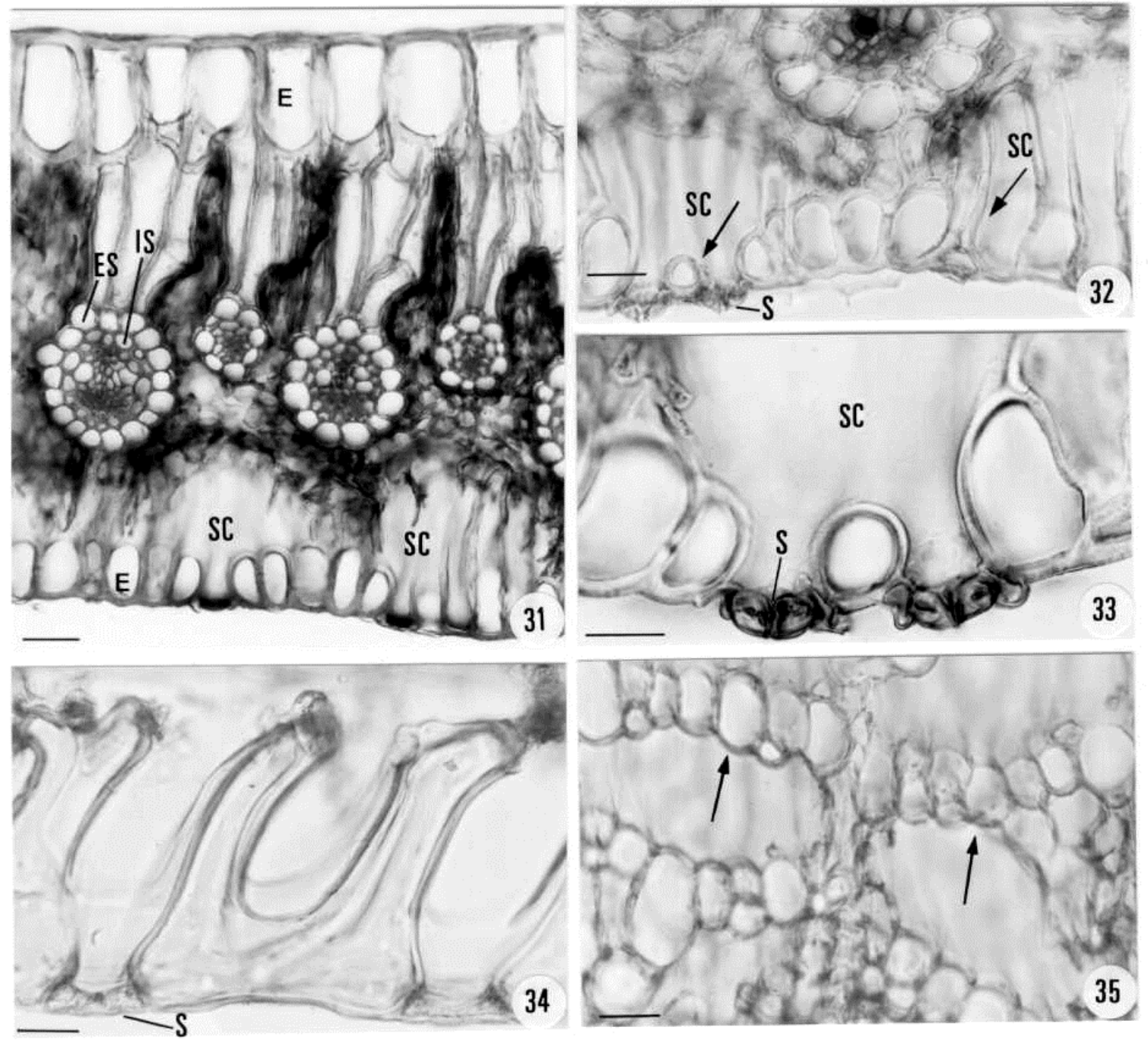

Figures 31-35 - Cross sections photographs of leaves of $P$. applanatus (Figs. 32-33) and P. macrocephalus (Fig. 31). Fig. 31 scale $=60 \mu \mathrm{m}$. Fig. 32 scale $=30 \mu \mathrm{m}$. Fig. 33 scale $=20 \mu \mathrm{m}$. Longitudinal (Fig. 34) and paradermical (Fig. 35) sections of $P$. geniculatus leaves. Fig. 34 scale $=30 \mu \mathrm{m}$. Fig. 35 scale $=50 \mu \mathrm{m} . \mathrm{E}=$ Epidermis; ES $=$ External Sheath; IS $=$ Internal Sheath; $\mathrm{S}=$ Stomata; $\mathrm{SC}=$ Substomatal Chambers

an important characteristic of the family. Stomata with special leaf substomatal chambers probably were related to the protection against the collapse of the substomatal chambers. Castro \& Menezes (1990) described for P. robustus and P. speciosus similar substomatal chambers. The authors related the presence of that chamber to the adaptation of the habitat where the species grew. They act in the largest efficiency of the gaseous changes. The presence of etomata with special leaf substomatal 
chambers is an important characteristic for the taxonomy of Eriocaulaceae.

The leaves of Aphorocaulon species showed epidermis with elongated cells in the adaxial face. This feature was observed in other species of Paepalanthus by Malmanche (1919) and Tomlinson (1969) and it seemed to be characteristic of the Paepalanthus species. The vascular bundles of all the eaves were collateral, the bigger ones alternating with the smaller ones as observed in other species of Paepalanthus studied by Castro (1986) and Scatena \& Moraes (1996). All of them possessed a double sheath: the external one was the endodermis and the internal one was the pericycle, for analogy as presented by Scatena \& Menezes (1996) for Syngonanthus species.

\section{ACKNOWLEDGEMENTS}

We thank Dr. Paulo Takeo Sano for supporting us with the use of the herbarium material and for discussions about these plants; Cybel Burgess for English review; Adelar Mantovani, Fernanda Faraco d'Eça Neves and Angelo Gilberto Manzatto for the paper's layout.

\section{RESUMO}

Estudou-se a anatomia de raízes, caules, folhas e escapos de espécies de Paepalanthus subseção Aphorocaulon. Estas plantas apresentam caules reduzidos com folhas em roseta, de onde crescem os paracládios (sistemas de inflorescências). As espécies apresentam raízes com epiderme unisseriada e córtex com células isodiamétricas. Tanto os caules reduzidos como os parach́dios apresentam espessamento resultante da atividade do periciclo, denominado Meristema de Espessamento Primário (MEP). Ambos apresentam estrutura anatômica semelhante. Os escapos apresentam endoderme descontínua, periciclo sinuoso, o córtex apresenta costelas salientes (5-6). As folhas apresentam células epidérmicas alongadas no sentido longitudinal com paredes levemente espessadas, estômatos somente na face abaxial, com câmara subestomática especializada, feixes vasculares colaterais com bainha dupla. Essas estruturas anatômicas são comuns para as espécies da subseção Aphorocaulon. Algumas características anatômicas observadas nestas espécies são típicas de plantas que crescem nos campos rupestres.

\section{REFERENCES}

Castro, N. M. (1986), Estudos morfológicos dos órgãos vegetativos de espécies de Paepalanthus Kunth. (Eriocaulaceae) da Serra do Cipó (Minas Gerais). Dissertação de Mestrado, Instituto de Biociências da Universidade de São Paulo, São Paulo, Brasil

Castro, N. M. \& Menezes, N. L. (1990), Considerações sobre a natureza das células altas da epiderme abaxial das folhas de Paepalanthus Kunth. - Eriocaulaceae. Bolm. Bot. Univ. S. Paulo, 12:95-100

Castro, N. M. \& Menezes, N. L. (1995), Aspectos da anatomia foliar de algumas espécies de Paepalanthus Kunth., Eriocaulaceae da Serra do Cipó (Minas Gerais). Acta. bot. bras., 9 (2): 213-229

Giulietti, A. M. \& Hensold, N. (1990), Padrões de distribuição geográfica dos gêneros de Eriocaulaceae. Acta bot. bras., 4 (1):133-159

Giulietti, A. M.; Amaral, M. C . E. \& Bittrich, V. (1995), Phylogenetic analysis of inter-and infrageneric relationships of Leiothrix Ruhland (Eriocaulaceae). Kew Bull., 50 (1): 55-71

Hensold, N. (1988), Morphology and systematics of Paepalanthus subgenus Xeractis (Eriocaulaceae). Sistematic Botany Monographs, Michigan: The American Society of Plants Taxonomists, Michigan, U.S.A.

Malmanche, L. A. (1919), Contribution à l'étude anatomique des Eriocaulacées et des families voisines. Restiacées, Centrolepidacées, Xyridacées, Philhydracées, Mayacacées. Tese, St. Cloud., Paris

Roeser, K. R. (1962), Die Nadel der Schwarzkiefer Massenprodukt und Kunstwert der Natur. Mikrokosmos, 61: 33-36

Sano, P. T. (1999), Revisão de Actinocephalus (Koern.) Sano Eriocaulaceae. Tese de Doutorado, Instituto de Biociências da Universidade de São Paulo, São Paulo, Brasil.

Scatena, V. L. \& Menezes, N. L. (1995), Aspectos morfológicos e anatômicos do caule em espécies de Syngonanthus Ruhl. Eriocaulaceae. Bolm. Bot. Univ. S. Paulo, 14, 91-107.

Scatena, V. L. \& Barros, A. M. (1996), Aspectos morfoanatômicos de Paepalanthus hilairei Koern. (Eriocaulaceae) da Serra do Cipó - MG. Arq. Biol. Tecnol., 39 (1) : 75-88. 
Scatena, V. L. \& Moraes, A. R. S. (1996), Anatomia de raízes, folhas e escapos de espécies de Paepalanthus subgênero Platycaulon (Eriocaulaceae). Arq. Biol. Tecnol., 39 (4) : 1021-1035.

Scatena, V. L. \& Menezes, N. L. (1996), Anatomia de escapos e folhas de Syngonanthus Ruhl. (Eriocaulaceae) de campos rupestres. Rev. Bras. Biol., 56 (2): 317-332
Scatena, V. L.; Cardoso, V. A. \& Giulietti, A. M. (1998), Anatomia do escapo floral de espécies brasileiras de Paepalanthus subgênero Platycaulon (Eriocaulaceae). Acta. bot. bras., 12 (2):121-133

Tomlinson, P. B. (1969), Commelinales-Zingiberales. In: Metcalfe, C.R. Anatomy of the Monocotyledons, Clarendon Press, Oxford
Received: August 24, 1999; Revised: October 21, 1999; Accepted: July 05, 2000. 